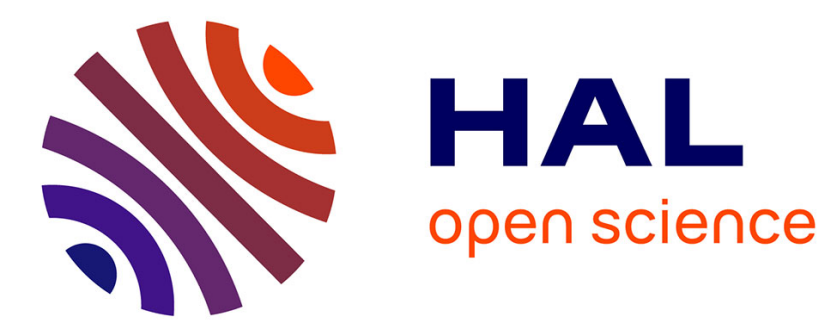

\title{
Extreme Heat and Stock Market Activity
}

Jonathan Peillex, Imane El Ouadghiri, Mathieu Gomes, Jamil Jaballah

\section{To cite this version:}

Jonathan Peillex, Imane El Ouadghiri, Mathieu Gomes, Jamil Jaballah. Extreme Heat and Stock Market Activity. Ecological Economics, 2021, 179, pp.106810. 10.1016/j.ecolecon.2020.106810 . hal02935431

\section{HAL Id: hal-02935431 \\ https://hal.science/hal-02935431}

Submitted on 10 Sep 2020

HAL is a multi-disciplinary open access archive for the deposit and dissemination of scientific research documents, whether they are published or not. The documents may come from teaching and research institutions in France or abroad, or from public or private research centers.
L'archive ouverte pluridisciplinaire HAL, est destinée au dépôt et à la diffusion de documents scientifiques de niveau recherche, publiés ou non, émanant des établissements d'enseignement et de recherche français ou étrangers, des laboratoires publics ou privés. 


\title{
Extreme Heat and Stock Market Activity ${ }^{1}$
}

\author{
Jonathan Peillex \\ ICD International Business School \\ Imane El Ouadghiri \\ Pôle Universitaire Léonard de Vinci \\ Mathieu Gomes \\ Université Clermont Auvergne, CleRMa \\ Jamil Jaballah \\ Grenoble Ecole de Management
}

\begin{abstract}
An ulterior version of this paper has been published in Ecological Economics: Peillex, J., El Ouadghiri, I., Gomes, M., Jaballah, J. (2020). Extreme Heat and Stock Market Activity. Ecological Economics, 179 (2021) 106810.

DOI: doi.org/10.1016/j.ecolecon.2020.106810
\end{abstract}

\begin{abstract}
We aim to advance our understanding of the adverse effects of extreme temperatures by examining the extent to which high temperatures affect stock market activity. We address this question by analyzing the trading volumes on the French stock market on days when the weather in Paris is excessively hot over the period 1995-2019. Our empirical analyses show that, on average, trading volumes fall significantly (between 4 percent and 10 percent) when maximum daily temperatures exceed $30^{\circ} \mathrm{C}\left(86^{\circ} \mathrm{F}\right)$. The observed negative association is remarkably robust to a battery of alternative analyses such as bin tests, event studies, and time-series regressions controlling for any seasonal effects and financial market conditions. From a theoretical perspective, this study contributes to the literature on behavioral finance by demonstrating the existence of a "hot weather" effect on financial markets. It also offers important managerial and public policy implications.
\end{abstract}

Keywords: behavioral finance, global warming, high temperatures, market activity, trading volume

\footnotetext{
${ }^{1}$ We gratefully acknowledge the financial support of Institut Louis Bachelier (ILB) and Institut Europlace de Finance (EIF).
} 


\section{Introduction}

The increase in global temperatures is only one facet of climate change. Another visible manifestation of climate change is the growing number of days on which the temperature is excessively high. Although the adverse effects of hot weather on the health of frail people are well identified (e.g., Otrachshenko et al., 2017; Kussel, 2018), we have relatively little understanding of its impact on employee activity (e.g., Chen and Yang, 2019; Hübler et al., 2008), particularly that of indoor workers such as investors. In this paper, we shed new light on this phenomenon by analyzing the extent to which high temperatures might negatively affect investor activity.

Identifying the factors that influence investor activity is highly important because financial market movements have a critical impact on the real economy. Prior research on behavioral finance tends to show that investors' financial decisions are not only the result of purely rational rules but are also subject to cognitive and emotional biases. In this context, a relatively large number of studies report the presence of anomalies on financial markets. The assumption shared by these studies is that external factors such as weather conditions influence both individuals and collective moods (e.g., Makridis, 2018) and, in turn, the propensity of investors to take risks. Thus, stock returns and volatility also depend on the degree of cloudiness (Saunders, 1993; Goetzmann et al., 2014), sunshine (Hirshleifer and Shumway, 2003; Bassi et al., 2013), humidity (Yoon and Kang, 2009), length of the day (Kamstra et al., 2003), and air pollution (Heyes et al., 2016). However, we know little about the consequences of temperatures on investors' financial decisions. Few studies (e.g., Cao and Wei, 2005) observe - with linear estimation methods - a negative relationship between the temperature and stock returns. Our study contributes directly to this strand of literature by isolating the specific influence of excessively high temperatures on the financial decisions of market agents. Moreover, in contrast to prior studies that mainly examine the effect of weather conditions on returns and volatility (e.g., Hou et al., 2019), our analysis focuses on trading volume. We posit that trading volume is a more appropriate measure of investor activity. 
Our starting point is the conjecture that excessively high temperatures could reduce investor activity for both physiological and psychological reasons. We argue that even though investors are more protected from weather conditions than outdoor workers, extreme heat may still increase the tiredness, the bad mood and the distraction of these indoor workers. Consequently, days with excessive heat should reduce investors' participation in the stock market. This hypothesis is in line with studies in behavioral finance revealing for instance that the amount of sunshine (Hirshleifer and Shumway, 2003; Bassi et al., 2013) or the degree of cloudiness (Saunders, 1993; Goetzmann et al., 2014) have a substantial impact on traders' decisions.

We test this conjecture by examining the trading volume on the French stock market on days with hot weather in Paris. The climatic context in France, particularly in the capital city, is interesting for at least three reasons. First, our data show that the number of days with a maximum temperature above $30^{\circ} \mathrm{C}\left(86^{\circ} \mathrm{F}\right)$ in Paris has increased significantly over the past five years (see Panel A of Table 1). Hence, a better understanding of the potential implications of extreme temperatures in France is of great importance. Second, France, in particular Paris, seems unprepared for heat waves. As such, according to the ADEME (Agency for the Environment and Energy Management), ${ }^{2} 4.5$ percent of housing in France (mostly in the south of France) and less than 25 percent of workplaces are air-conditioned. Additionally, in terms of public transportation, 94 percent of buses in Paris and 40 percent of Paris' railway network are not yet air-conditioned. Third, the French stock market is one of the European stock markets featuring the lowest proportion of trading by non-residents ${ }^{3}$. In addition, the vast majority of French investors are based

\footnotetext{
${ }^{2}$ https://www.ademe.fr.

${ }^{3}$ According to the French Council for Economic Analysis, only 39\% of all French listed firms' equity were held by non-residents in 2016. Source: http://www.cae-eco.fr/IMG/pdf/cae-focus021.pdf.
} 
in Paris ${ }^{4}$. This combination of low participation by non-residents and high proportion of French asset managers based in Paris makes the French context particularly suited to our study.

In this paper, we assume that the trading volume, in comparison with stock prices (and therefore with returns), is a better way to measure investor activity. Trading volume refers to the total amount of trading (both purchasing and selling) of stocks. A low trading volume may then indicate investors' disinterest and discouragement in placing orders, which could result from the harmful consequences of excessively hot weather. The price (and by extension, returns) does not necessarily reflect market activity but, rather, a value that depends on the movements of purchasing and selling. Investors can thus be particularly active in terms of trading volume without necessarily affecting the returns significantly and vice versa. In addition, investigating the impact of high temperatures on trading volumes is interesting in at least two more respects. First, better identifying the determinants of trading volumes is important for nvestors who generally prefer higher daily trading volumes (because when volumes are high, buying and selling at a desired price is easier). Second, advancing our understanding of the factors that drive trading volumes also contributes to the financial markets literature since trading volume plays a substantial function in research works on liquidity, return, and volatility predictability.

Because days with excessively high temperatures generally occurred in July and August, we employ empirical methods that ensure our estimation results are caused by excessive high temperatures rather than driven by investors being on vacation (July and August corresponding to the French summer holidays). In particular, instead of utilizing raw trading volume variables, we follow Peress and Schmidt (2020) in using seasonally-adjusted trading volume variables to make sure the results are not caused by calendar patterns. We use three different empirical approaches

\footnotetext{
${ }^{4}$ According to the AMF (Autorité des Marchés Financiers, i.e., the French market regulator), 554 (or roughly 88\%) out of 633 registered French asset managers were based in the Paris area in 2018. Source: https://www.amf-france.org/
} 
to assess the influence of high temperatures on deseasonalized trading volumes: (i) a binning approach, (ii) an event study, and (iii) time-series regressions controlling for financial market conditions. Based on a binning approach, our first empirical analysis reveals that the average trading volumes are the lowest on the bin covering the highest temperature range. In the same direction, our second analysis provides evidence that when temperatures in Paris exceed $30^{\circ} \mathrm{C}$ $\left(86^{\circ} \mathrm{F}\right)$, trading volume on the French market falls significantly (between 4 percent and 10 percent, depending on the event study setting). Finally, the time-series regressions confirm that excessively high temperatures reduce significantly trading volume even after explicitly controlling for financial variables at the market level. We discuss the academic, political, and managerial implications of these findings in the conclusion.

\section{Theoretical foundation and hypothesis development}

We rely on the behavioral finance literature and previous works that link heat stress with mood and worker productivity to discuss the theoretical role that extreme heat can have on investors' activity. We argue that there is causal link between extreme heat and interconnected physiological as well as psychological factors such as (i) "tiredness", (ii) "mood" and, (iii) "distraction", and that each of these three factors may affect investors' propensity to trade.

From a physiological perspective, when temperatures are high, the human body needs more energy to cool down. This cooling process reduces the energy available for work and eventually leads to general tiredness or even apathy. Fatigue does not only affect physical performance, it also deteriorates mental and cognitive functions (Abd-Elfattah et al., 2015). This argument is often mobilized by empirical studies in labor economics to explain the lower productivity of outdoor workers during hot days (e.g., Hübler et al., 2008; Chen and Yang, 2019; ILO, 2019). In this context, several studies also suggest that excessively high temperatures lead outdoor workers to take more breaks or even reduce their worktime (Graff Zivin and Neidell, 2012; Somanathan et al., 2015). 
While it is likely that indoor workers such as investors may benefit from air conditioning in the office buildings, high outdoor temperatures may also amplify their tiredness. Indoor workers may "import" the consequences of outdoor temperature when commuting between home and work, or after a break. For instance, these workers potentially "protected" by climate control system at the workplace, may be substantially exposed to heat when they use public transportation which is often crowded and where the heat may be suffocating, or when they are walking outside (e.g., Cao and Wei, 2005). Moreover, some of them who cannot lower the temperature in their homes, may therefore suffer from migraines and a deterioration in the quality of their sleep (Zander et al., 2015). These arguments may particularly prevail in countries such as France, where, as discussed above, public transport and housing are relatively poorly equipped with air conditioning. Research works that examine the link between outside temperature and the productivity of indoor workers are relatively scarce. However, there is a narrow literature strand revealing that, beyond a certain threshold, daily outside temperature deteriorate students' cognitive performance (Cho, 2017; Park, 2016; Graff Zivin et al., 2018). In a similar way as studying, it is arguable that trading is a highly cognitively demanding activity. Consequently, the physical discomfort caused by severe heat could also negatively affect investors' concentration and impair their decision-making ability, ultimately leading to a decrease in market activity.

From a psychological point of view, it has been recognized that excessively high temperatures impact individuals' mood or emotional state. Indeed, several factors arising from extreme heat such as sleep disturbance, unfavorable public transportation conditions, and even sweating eventually irritate individuals. For instance, by using a billion of geocoded Twitter updates, Baylis (2015) finds a decline of the hedonic state (measured by the number of profanity and negative emoticons) when the temperature is high. In that vein, Heyes and Saberian (2019) recently document that during days of excessively high outdoor temperature, immigration judges (which are indoor workers) are more likely to take decisions unfavorable to the applicants than during 
cooler days. Other studies demonstrate that heat stress increases violence and conflicts (e.g., Anderson, 1987; Hsiang et al., 2013).

With regard to research works in finance, numerous empirical studies document that weather conditions influence investors' mood states and ultimately their financial decisions. Specifically, most of these research works posit that favorable (unfavorable) weather conditions should induce optimistic (pessimistic) emotional states, which in turn should positively (negatively) impact stock returns. Under this view, it has been shown that cloud cover (or lack of sunshine), the length of the night, or the air pollution exert a negative impact on stock returns (e.g., Saunders, 1993; Hirshleifer and Shumway, 2003; Kamstra et al., 2003; Goetzmann et al., 2014; Heyes et al., 2016). These weather effects are significant despite the fact that traders tend to work indoors and often in windowless trading rooms. Consequently, it is reasonable to argue that high outdoor temperatures should affect investor activity no less than the degree of cloudiness, the length of the day, or air pollution. This mood effect can be particularly important for the French population and in particular Parisians, which are not accustomed to extremely high temperatures. Indeed, in Paris, even though the number of days when temperatures exceed $30^{\circ} \mathrm{C}$ is growing, such extreme temperatures are still uncommon.

Extreme heat may induce another psychological effect, namely a "distraction" effect. Very hot weather can indeed distract individuals, especially in countries like France where these events are infrequent. These hot days can then become episodes, subjects of discussion and debate, which can potentially lead investors to shift their focus from finance to temperature issues and thus reduce market activity. Furthermore, since elderly and very young people are the most vulnerable to heat wave (e.g., Otrachshenko et al., 2017; Kussel, 2018), this can be a source of concern for workers with families. Against this background, previous studies find that some events exogenous to the stock market distract (or divert) investors' attention. For instance, Kaplanski and Levy (2010) document a negative association between football World Cups and stock returns. Similarly, Peress 
and Schmidt (2020) reveal that sensational news with a larger surge in TV viewership such as O.G. Simpson's trial negatively affect market activity.

Based on the arguments discussed above, we hypothesize that extreme heat should increase the tiredness, the negative mood, and the distraction of investors. Consequently, on days with severe heat, it is arguable that investors should be less motivated in placing orders, which should lower the trading volume.

\section{Data, methodology and results}

\subsection{Data}

To identify days with severe heat that potentially affect the trading volume on the French stock market, we collect the maximum daily temperatures in Paris for the period January 1, 1995, to December 31, $2019(\mathrm{~N}=8,853)^{5}$ from the French meteorological website Infoclimat ${ }^{6}$. We consider a day to be especially hot when the daily maximum temperature in Paris exceeds $30^{\circ} \mathrm{C}\left(86^{\circ} \mathrm{F}\right)(\mathrm{e} . \mathrm{g}$., Addoum and Ortiz-Bobea, 2019). We choose this temperature threshold for two main reasons. First, the meteorological services in France (and in Western Europe generally speaking) consider that there is a risk of heat wave when the daily maximum temperatures exceed $30^{\circ} \mathrm{C}\left(86^{\circ} \mathrm{F}\right)$. Second, when we divide the French temperatures series into four bins, the fourth bin contains temperatures in the range $\left[30.075^{\circ} \mathrm{C}, 41.9^{\circ} \mathrm{C}\right]$ (for more details on the temperature range of each bin, refer to the next section). With regard to the whole period, the days when the maximum temperature exceeds $30^{\circ} \mathrm{C}\left(86^{\circ} \mathrm{F}\right)(\mathrm{N}=352)$ are recorded in May $(\mathrm{N}=5)$, June $(\mathrm{N}=63)$, July $(\mathrm{N}$ $=141)$, August $(\mathrm{N}=131)$, and September $(\mathrm{N}=12)$. On average, we observe 14 days per year with temperatures excessively high.

\footnotetext{
${ }^{5}$ The size of this initial sample of 25 years is similar to that of other studies examining the effects of weather on financial markets (e.g., Hirshleifer and Shumway, 2003; Yoon and Kang, 2009; Goetzmann et al., 2014).

${ }^{6}$ http://www.infoclimat.fr.
} 
Panels A and B in Table 1 display the descriptive statistics of daily maximum temperatures in Paris. We find a significant increase in the number of days when the maximum temperature exceeds $30^{\circ} \mathrm{C}\left(86^{\circ} \mathrm{F}\right)$ over the past five years (i.e., 107 for the recent subperiod $2015-2019,44$ for the subperiod 2010-2014, and around 60 for the other subperiods). We observe a similar pattern in the number of days with temperatures exceeding $31^{\circ} \mathrm{C}\left(87.8^{\circ} \mathrm{F}\right), 32^{\circ} \mathrm{C}\left(89.6^{\circ} \mathrm{F}\right), 33^{\circ} \mathrm{C}\left(91.4^{\circ} \mathrm{F}\right)$ and $34^{\circ} \mathrm{C}\left(93.2^{\circ} \mathrm{F}\right)$. In addition, it appears that the average maximum temperature in Paris has also increased over the past half-decade (i.e., $17.4^{\circ} \mathrm{C}\left[63.3^{\circ} \mathrm{F}\right]$ in the most recent subperiod $2015-2019$ and around $16^{\circ} \mathrm{C}\left[60.8^{\circ} \mathrm{F}\right]$ in the previous subperiods).

In this article, we focus on the SBF250 stock market index, which includes the 250 French stocks with the biggest market capitalizations. We collect the daily trading volume on this index from the Bloomberg terminal. This variable is defined as the number of shares traded on a day. We naturally keep only the trading days, i.e., days when the French stock exchange is open $(\mathrm{N}=$ 6,359). Panel $\mathrm{C}$ in Table 1 reports the descriptive statistics of the daily trading volume on the SBF250 stock index.

\section{Insert Table 1 Around Here}

\subsection{Deseasonalizing-a safeguard against spurious correlations}

In this subsection, we propose to discuss several effects that may induce a spurious link between excessively high temperatures and trading volume. Then, we present the empirical strategy we apply to protect our empirical results against spurious correlations.

First, it has been proven that market activity tends to slow down during holidays (e.g., Jacobs and Weber, 2012). Therefore, it seems crucial to disentangle the French "summer vacation" effect on trading volume from the "hot weather" effect because most days with hot weather in Paris are recorded, in July and August. Second, previous research works on behavioral finance document that the days of the week, particularly Monday, significantly impact market activity (e.g., Fishe et 
al., 1993). For instance, the Monday effect may be explained by a mood deterioration but also by an informational mechanism. Indeed, the amount of information published during a two-day weekend can be substantial. As a result, investors may need more time to digest these information flows after these two days off, which can result in a reduction in trading volumes on Monday. Thus, it is also important to account for the days of the week effect in our empirical setting. Finally, as shown in Panel C of Table 1, the average trading volume on the SBF250 index significantly varies from one half-decade to another. Consequently, it also seems critical to rigorously control for potential year effects on trading volume.

To ensure that the effect of high temperatures on trading volume is distinct from the influence of the French summer vacation, the Monday or the year on market activity, we propose to carry out our empirical tests on the basis of deseasonalized trading volumes. To do so, in accordance with Peress and Schmidt (2020), we follow a two-step approach. In a first step, we regress trading volume on a large set of calendar controls, including month, day of the week and year dummies as follows:

$\operatorname{Ln}\left(V O L U M E_{S B F 250, t}\right)=\alpha_{1}+\sum_{i=1}^{11} \delta_{i} M O N T H_{i, t}+\sum_{i=1}^{4} \lambda_{i} D A Y_{i, t}+\sum_{i=1}^{24} \varphi_{i} Y E A R_{i, t}+\varepsilon_{t}$

Where $\operatorname{Ln}\left(V O L U M E_{S B F 250, t}\right)$ is the natural logarithm of the trading volume on the SBF250 stock index on day t. $M O N T H_{i, t}$ is a column vector comprising 11 dummy variables that take the value one if day $\mathrm{t}$ belongs to the corresponding month. Similarly, the vector $D A Y_{i, t}$ comprises 4 dummy variables (Monday, Tuesday, Wednesday and Friday) coded as one if day $\mathrm{t}$ belongs to the corresponding day. In accordance with Capelle-Blancard et al. (2019), YEAR $R_{i, t}$ takes into account 24 dummy variables for the years from 1995 to 2019. Finally, $\varepsilon_{t}$ denotes the error term. Eq. 1 assumes that the trading volume on day $\mathrm{t}$ is affected by the corresponding month, day of the week and year. 
In a second step, we store the residuals from this time-series regression. These residuals correspond to the deseasonalized trading volumes, i.e., trading volumes purged from seasonal effects. These residuals are then used in the following empirical analyses, which provides a solid safeguard against spurious correlations.

\subsection{Bin tests-Is market activity sensitive to extreme heat?}

In line with the climate econometrics literature (e.g., Cao and Wei, 2005; Cho, 2017), we start by using a "binning" approach to have a first look at the nature of the relationship between temperatures and market activity. This approach allows us to represent the distribution of French temperatures, and then, to compare the average trading volume on the SBF250 index associated with the bin covering the highest and those that contain the lowest French temperatures. In accordance with Cao and Wei (2005), we calculate the temperature range of each bin $(\Delta)$ as follows:

$$
\Delta=\frac{T e m p_{\max }-T e m p_{\min }}{4}
$$

Where $T e m p_{\max }$ and $T e m p_{\min }$ denote the maximum and the minimum of the daily maximum French temperature series, respectively. The denominator (i.e., 4) corresponds to the desired number of bins. The first, the second, the third and the fourth bin contain temperatures in the range $\left[\right.$ Temp $_{\text {min }}$, Temp $_{\text {min }}+\Delta\left[;\left[\right.\right.$ Temp $_{\text {min }}+\Delta$, Temp $_{\min }+2 \Delta\left[;\left[\right.\right.$ Temp $p_{\text {min }}+2 \Delta$, Temp $_{\text {min }}+3 \Delta[;$ and $\left[T e m p_{\min }+3 \Delta, T e m p_{\min }+4 \Delta\right]$, respectively. The fourth bin corresponds to the temperatures in the range $\left[30.075^{\circ} \mathrm{C}, 41.9^{\circ} \mathrm{C}\right]$, which makes it crucial to assess the effect of excessively hot days on trading volumes.

Then, following Saunders (1993), we perform $z$-tests to estimate the statistical significance of the difference between the average trading volume on the SBF250 index associated to the fourth 
bin (the bin of interest to test our conjecture) and those for the first, the second, and the third bin, respectively. We compute the $z$-scores as follows:

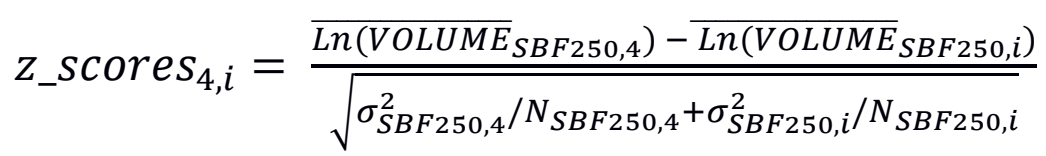

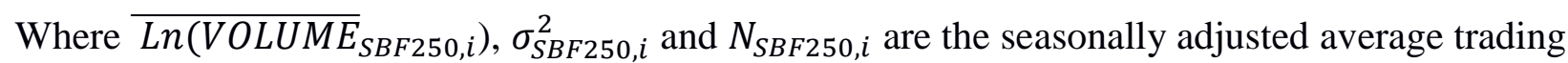
volume taken in logarithm ${ }^{7}$, the variance and the number of observations of bin $i(i=\{1,2,3\})$.

In Table 2, we report the difference in percentage between the average deseasonalized trading volume for bin $i(i=\{1,2,3\})$ and bin 4 (i.e., the bin that contains the highest temperatures) with the corresponding $z$-score. With regard to the whole period, we find that the average trading volume on the SBF250 index for the fourth temperature bin $\left(\left[30.075^{\circ} \mathrm{C}, 41.9^{\circ} \mathrm{C}\right]\right)$ is lower than that of bin 1 (- 6 percent), bin 2 (- 9 percent) and bin 3 (- 6 percent). In the clear majority of cases, we also observe for the five subperiods, negative differences between the average trading volume on the SBF250 index for the fourth temperature bin and those for the other bins covering lower temperatures.

\section{Insert Table 2 Around Here}

Our previous analyses presented in Table 2 showed the results for the SBF250 index, which is composed of a relatively large number of French stocks. We now verify that the results are robust if instead we examine the average trading volume on the CAC40 index, which tracks the largest 40 French stocks in terms of market capitalization. Reported in Table 3, the results for the CAC40 index are very similar to those for the SBF250 index. For the whole period, we find that the average deseasonalized trading volume on the CAC40 index for the fourth temperature bin is

\footnotetext{
${ }^{7}$ Please refer to the previous sub-section "Deseasonalizing- a safeguard against spurious correlations" for details on the method used to deseasonalize trading volumes variables.
} 
less important than the other bins covering lowest temperatures (- 8 percent in comparison with bin 1, - 8 percent in comparison with bin 2, and - 7 percent in comparison with bin 3 ). The analysis by half decades confirms these results. Indeed, with the exception of bin 1 for the 2010-2014 subperiod, the differences between bin 4 and the other bins are all negative.

\section{Insert Table 3 Around Here}

By showing that the average trading volumes are the lowest on the bin covering the highest temperature range (i.e., bin 4), this first empirical analysis tends to confirm our conjecture that excessively high temperatures tend to reduce market activity. In the next subsection, we perform an event study to analyze more deeply the consequences of days when the temperature is in the fourth bin. This approach enables us to quantify more precisely the extent of the decline in market activity during excessively hot days.

\subsection{Event study-to what extent does market activity decrease on days with hot weather?}

In accordance with the literature on financial markets' reactions (e.g., Gupta and Goldar, 2005; Takeda and Tomozawa, 2008; Peress and Schmidt, 2020), we employ an event study methodology to estimate the extent to which the trading volume falls during days with intense heat. As we focus on a stock market index, we do not adopt a standard market model to compute the theoretical (or expected) trading volumes. This would lead to regressing the market on the market, inducing perfect endogeneity.

We thus estimate the theoretical seasonally-adjusted trading volume through the following meanadjusted $\operatorname{model}^{8}$ :

\footnotetext{
${ }^{8}$ Despite the apparent simplicity of the mean-adjusted model, previous studies have shown that it yields results very similar to those of more sophisticated models (e.g., Brown and Warner, 1985).
} 


$$
\operatorname{Ln}\left(\widehat{\operatorname{VOLU} M} E_{S B F 250, t}\right)=\operatorname{Ln}\left(\overline{\operatorname{VOLUME}}_{S B F 250, t}\right)
$$

This model assumes that the theoretical trading volume on the SBF250 index at day $t$ $\left(\operatorname{Ln}\left(\widehat{V O L U} M E_{S B F 250, t}\right)\right)$ equals the mean volume of this index $\left.\left({\overline{\operatorname{Ln}\left(V O L U M E_{S B F 250, t}\right.}}\right)\right)$ over a previous time interval (i.e., the estimation period). We consider four alternative time intervals (i.e., $[-200,-1],[-100,-1],[-30,-1]$, and $[-15,-1])$ to compute the mean volume of the SBF250. These relatively short estimation windows make it possible to correct one of the limitations of the binning approach. Indeed, the binning methodology uses average trading volume which are calculated over very long periods (several years) that can mask important changes in financial market conditions. Moreover, even though our empirical analysis is based on seasonally adjusted data, the shortest event window, i.e. $[-15,-1]$ offers a second safeguard against the potential confounding effect of French summer holidays.

Then, the daily abnormal deseasonalized trading volume for the SBF250 index at day $t$ $\left(A V O L U M E_{S B F 250, t}\right)$ is calculated as the difference between the actual volume and the expected trading volume, i.e.:

$$
A V O L U M E_{S B F 250, t}=\operatorname{Ln}\left(V O L U M E_{S B F 250, t}\right)-\operatorname{Ln}\left(\widehat{V O L U M} E_{S B F 250, t}\right)
$$

Finally, we aggregate the abnormal deseasonalized trading volume of the SBF250 index for each event, namely, days when the temperature is excessively high. This aggregation $\left(A A V O L U M E_{S B F 250}\right)$ is obtained by averaging the abnormal seasonally-adjusted trading volume for T excessively hot days, i.e.:

$$
A A V O L U M E_{S B F 250}=\frac{1}{T} \sum_{t=1}^{T} A V O L U M E_{S B F 250, t}
$$


Following the previous literature (e.g., Capelle-Blancard and Laguna, 2010), we assess the statistical significance of the abnormal average trading volume by performing a standard $t$-test. ${ }^{9}$

We start by presenting the abnormal average deseasonalized trading volume (AAVOLUME) on the SBF250 stock index on days with temperatures exceeding $30^{\circ} \mathrm{C}\left(86^{\circ} \mathrm{F}\right), 31^{\circ} \mathrm{C}\left(87.8^{\circ} \mathrm{F}\right)$, $32^{\circ} \mathrm{C}\left(89.6^{\circ} \mathrm{F}\right), 33^{\circ} \mathrm{C}\left(91.4^{\circ} \mathrm{F}\right)$, and $34^{\circ} \mathrm{C}\left(93.2^{\circ} \mathrm{F}\right)$, respectively. ${ }^{10}$ For each of these temperature thresholds, in Table 4 we report the AAVOLUME in percentage (with the corresponding zstatistics), as well as counts of positive and negative individual AVOLUME (with the corresponding sign $z$-statistics). Panel A shows these results when we use the time interval [-200, -1] to compute the theoretical (expected) trading volumes while Panel B Panel C, and Panel D display these results for the estimation window $[-100,-1],[-30,-1])$, and $[-15,-1]$, respectively.

It appears that the AAVOLUMEs are negative and significant when the daily maximum temperature exceeds $30^{\circ} \mathrm{C}\left(86^{\circ} \mathrm{F}\right)$ independently of the estimation window considered. For instance, AAVOLUME for the SBF250 stock index are -7 percent $(z=-4.94),-6$ percent $(z=-$ 4.47), -5 percent $(z=-3.50)$, and -4 percent $(z=-3.00)$ for Panels $A, B$, and $C$, respectively. The magnitude of the observed values is quite similar to those displayed in the event study of Peress and Schmidt (2020). This indicates that the days when the temperature exceeds $30^{\circ} \mathrm{C}\left(86^{\circ} \mathrm{F}\right)$ have an adverse effect on investor activity at least as important as non-economic sensational news which captivate the maximum attention of television channels. In addition, a majority of the 233 individual AVOLUMEs are negative (144 negative vs. 89 positive for Panel A; 145 negative vs. 88 positive for Panel B; 147 negative vs. 86 positive for Panel C and 138 negative vs. 95 positive

\footnotetext{
${ }^{9}$ More precisely, we start by calculating an individual $t$-statistic for each $A V O L U M E_{S B F 250, t}$. Then, we obtain the $z$-statistic for the AAVOLUM $E_{S B F 250}$ by summing the individual $t$-statistics that we divide by the square root of the number of events.

${ }^{10}$ Note that the number of hot days is less important in Table 4 than in Table 1 because the non-trading days were naturally excluded from the analysis.
} 
for Panel D). Finding negative AAVOLUMEs supports the results from the bin tests and our hypothesis — namely, that high temperatures diminish market activity.

To study whether higher temperatures (above $30^{\circ} \mathrm{C}$ ) reinforce the negative effect on trading volume, we also present the AAVOLUMEs when temperatures exceed $31^{\circ} \mathrm{C}\left(87.8^{\circ} \mathrm{F}\right), 32^{\circ} \mathrm{C}$ $\left(89.6^{\circ} \mathrm{F}\right), 33^{\circ} \mathrm{C}\left(91.4^{\circ} \mathrm{F}\right)$, and $34^{\circ} \mathrm{C}\left(93.2^{\circ} \mathrm{F}\right)$, respectively. This analysis allows us to have a deeper understanding of the consequences of other temperature levels inside the fourth bin. For each of these temperature thresholds, we still observe highly significant negative AAVOLUMEs on the SBF250 stock index. However, it seems that AAVOLUMEs for these higher thresholds are similar to those on days when the temperature exceeds $30^{\circ} \mathrm{C}\left(86^{\circ} \mathrm{F}\right)$. Therefore, above $30^{\circ} \mathrm{C}\left(86^{\circ} \mathrm{F}\right)$, our results do not indicate the presence of a linear relationship between the temperature and the decline in market activity.

\section{Insert Table 4 Around Here}

We then perform a series of robustness checks, presented in Tables 5, 6, and 7, which address potential concerns. First, we check that our results are equivalent when we examine the seasonallyadjusted trading volume on the CAC40 index. Results are reported in Table 5 and reveal that the AAVOLUMEs for the CAC40 index are qualitatively similar to those for the SBF250 index. Specifically, we find that the trading volume on the CAC40 index is significantly lower when the maximum daily temperature is above $30^{\circ} \mathrm{C}\left(86^{\circ} \mathrm{F}\right)(-8$ percent in Panel $\mathrm{A},-8$ percent in Panel $\mathrm{B}$, 6 percent in Panel C, and -5 percent in Panel C). Furthermore, out of 233 individual AVOLUMEs, 155, 153, 146, and 138 are negative in Panels A, B, C, and D, respectively. Thus, this additional analysis confirms our main results.

\section{Insert Table 5 Around Here}


Second, to confirm that our results are not driven by the effect of French summer vacations, we propose to recompute the AAVOLUMEs on the SBF 250 index during July and August. ${ }^{11}$ More precisely, in Table 6, we compare the AAVOLUMEs for days on which the maximum temperature is above $30^{\circ} \mathrm{C}\left(86^{\circ} \mathrm{F}\right)$ during the July-August period with those for cooler days (placebo events) during the same period. During the French summer holidays, results in Panel A indicate that AAVOLUMEs on the SBF250 on hot days $\left(>30^{\circ} \mathrm{C}\right)$ are still negative and statistically significant. By contrast, results in Panel B show that AAVOLUMEs on cooler days $\left(<30^{\circ} \mathrm{C}\right)$ are very close to 0 percent during this July-August period. This reveals that market activity does not decline when the maximum daily temperature is below $30^{\circ} \mathrm{C}\left(86^{\circ} \mathrm{F}\right)$ during the French summer vacation. This additional falsification test allows to guarantee that the hot days results are driven by the climatic events themselves, rather than due to the specific period of the year (i.e., the annual summer holidays effect).

\section{Insert Table 6 Around Here}

Finally, to study whether the adverse effect of high temperatures on trading volume has changed over time, we repeat the analyses in Tables 4 and 5 separately for events that occurred across the half-decades of the sample (i.e., 1995-1999, 2000-2004, 2005-2009, 2010-2014, and 2015-2019). Table 7 presents these results for days with a maximum temperature exceeding $30^{\circ} \mathrm{C}$ $\left(86^{\circ} \mathrm{F}\right)$ based on the estimation window $[-100,-1]$. We find that AAVOLUMEs for both the SBF250 index (see Panel A) and the CAC40 index (see Panel B) are negative for each half-decade. In addition, the negative impact of high temperatures on market activity has not monotonically increased (or decreased) over time.

\footnotetext{
${ }^{11}$ The results on the CAC 40 index are highly similar to those on the SBF 250 index. They are not reported here but are available from the corresponding author upon request.
} 


\section{Insert Table 7 Around Here}

\subsection{Time-series regressions-controlling for other rationales for unusual trade volumes}

The two previous empirical analyses, namely the bin tests and the event study, both indicate that trading volumes on the French stock market drop significantly on days when the weather in Paris is excessively hot. Since these two empirical approaches are based on seasonally-adjusted trading volumes, they control for the effect of known anomalies such as the summer holidays effect and the Monday effect. However, they do not explicitly control for other financial rationales for unusual trade volumes. In this section, we investigate whether the "hot weather" effect on financial markets persists after controlling for financial market conditions.

In line with Kamstra et al. (2003), we include two lagged deseasonalized trading volumes in our multivariate regression setting to control for residual correlation. In addition, because the trading levels in other parts of the world may impact the trading volumes on the French stock market, we also control for the seasonally-adjusted trading volume on a US stock index (i.e., the MSCI USA index). Finally, due to the potential correlation between returns' volatility and trading volumes (e.g., Foster and Viswanathan, 1993), we also include in our multivariate regression model the daily returns volatility on the SBF250 stock index. Thus, to assess more rigorously the effect of days with severe heat on deseasonalized trading volumes by controlling for such financial variables, we estimate the following model:

$$
\begin{aligned}
& \operatorname{Ln}\left(V O L U M E_{S B F 250, t}\right)=\alpha_{1}+\alpha_{2} D A Y S>30^{\circ} C_{t}+\alpha_{3} \operatorname{Ln}\left(V O L U M E_{S B F 250, t-1}\right)+ \\
& \alpha_{4} \operatorname{Ln}\left(V O L U M E_{S B F 250, t-2}\right)+\alpha_{5} \operatorname{Ln}\left(V O L U M E_{M S C I U S A, t}\right)+\alpha_{6} V O L A T I L I T Y_{S B F 250, t}+\varepsilon_{t}
\end{aligned}
$$

Where $\operatorname{Ln}\left(\operatorname{VOLUME_{SBF250,t}}\right)$ is the seasonally adjusted trading volume on the SBF250 stock index on day $\mathrm{t}$ taken in logarithm. The independent variable of interest $D A Y S>30^{\circ} C_{t}$ is a dummy variable which equals one when the maximum temperature exceeds $30^{\circ} \mathrm{C}\left(86^{\circ} \mathrm{F}\right)$ during the trading 
day $\mathrm{t}$ and equals zero otherwise. $\operatorname{Ln}\left(V O L U M E_{S B F 250, t-1}\right)$ and $\operatorname{Ln}\left(V O L U M E_{S B F 250, t-2}\right)$ denote the lagged deseasonalized trading volumes on the SBF250 stock taken in logarithm. These variables allow us to control for the first and second-order auto-correlations in trading volumes, respectively. $\operatorname{Ln}\left(V O L U M E_{M S C I} U S A, t\right)$ is the seasonally adjusted trading volume on the MSCI USA stock index on day $\mathrm{t}$ taken in logarithmic value. With 636 constituents, this stock index covers around $85 \%$ of the free float-adjusted market capitalization in the US. VOLATILITY $Y_{S B F 250, t}$ denotes the conditional volatility on the SBF250 stock index obtained from a GARCH(1,1) model in day t. Finally, $\varepsilon_{t}$ denotes the error term. We apply least squares regressions where the coefficients are estimated using heteroskedasticity-robust standard errors.

We report in Table 8 the results from our OLS regressions which aim to assess the effect of excessively hot weather on the deseasonalized trading volumes on the SBF250 stock index. In Model 1 of Table 8, we first show the regression outcome comprising the independent variable of interest only (i.e., $D A Y S>30^{\circ} C_{t}$ ). Thus, this econometric specification replicates, to a certain extent, the event study presented previously. As predicted, the parameter estimates for the variable $D A Y S>30^{\circ} C_{t}$ is negative and statistically different from zero at the one percent significance level $(\mathrm{p}<0.01)$. The importance of the coefficient assigned to the variable $D A Y S>30^{\circ} C_{t}$ (i.e., -0.07 ) suggests that this variable of interest also matters strongly in terms of economic significance. Indeed, when the temperatures in Paris exceed $30^{\circ} \mathrm{C}\left(86^{\circ} \mathrm{F}\right)$, the trading volume on the SBF250 stock index decreases by 7 percent on average.

We then incrementally augment this baseline model by adding financial variables in Model 2 (i.e., the full model described in Eq. (7)). The variable $D A Y S>30^{\circ} C_{t}$ continues to robustly exert a negative impact on the deseasonalized trading volume on the SBF250 stock index. From the economic significance perspective, this second model shows that the trading volume on the SBF250 index drops by 5 percent during days with severe heat. Moreover, as expected, the 
parameter estimates for the financial control variables $\operatorname{Ln}\left(V O L U M E_{S B F 250, t-1}\right)$, $\operatorname{Ln}\left(V O L U M E_{S B F 250, t-2}\right)$, and $\operatorname{Ln}\left(V O L U M E_{M S C I U S A, t}\right)$ are always positive and significantly different from zero.

\section{Insert Table 8 Around Here}

To confirm the robustness of our findings, we provide the results on the CAC40 instead of the SBF250 stock index in Table 9. The results are qualitatively similar to the estimates of previous models on the SBF250 stock index. Indeed, the full model in Table 9 (i.e., Model 2) shows negative and statistically significant effects of the variable $D A Y S>30^{\circ} C_{t}(\alpha=-0.05, \mathrm{p}=0.00)$ on the seasonally adjusted trading volumes on the CAC40 stock index.

\section{Insert Table 9 Around Here}

Therefore, this additional empirical analysis based on deseasonalized trading volume variables reveals that the "hot weather" effect remains present after controlling for other financial rationales for unusual trade volumes. Ceteris paribus, days when the weather in Paris is excessively hot tend to decrease the trading volumes on the French stock market. Note that, instead of using deseasonalized trading volume, following Kaplanski and Levy (2010), we also have run regressions by using the raw trading volume as dependent variable and adding July-August, Monday and year dummy variables. Unreported here, the results from this supplementary analysis corroborate our main findings, i.e., the negative influence of hot days events on market activity.

At this point, it could be interesting to investigate how the trading volumes react on subsequent days when temperatures return to normal levels. In order to assess the potential rebounds of trading volumes after days of severe heat, we rerun Eq.7 by sequentially replacing the variable of interest $D A Y S>30^{\circ} C_{t}$ by the binary variables $D A Y S>30^{\circ} C_{t+1}, D A Y S>30^{\circ} C_{t+2}, D A Y S>30^{\circ} C_{t+3}$, and $D A Y S>30^{\circ} C_{t+4}$. These dummy variables are respectively coded as one for the first, the 
second, the third and the fourth day following the day with hot weather in Paris and zero otherwise. Table 10 contains these results for the SBF250 index. We also have performed this analysis for the CAC40 index. The results remain qualitatively very similar to those observed for the SBF250 index.

\section{Insert Table 10 Around Here}

In Table 10, we observe that the parameter estimates associated with $D A Y S>30^{\circ} C_{t+1}$ (see Model 1), DAYS $>30^{\circ} C_{t+2}$ (see Model 2), DAYS $>30^{\circ} C_{t+3}$ (see Model 3), and DAYS $>$ $30^{\circ} C_{t+4}$ (see Model 4) are invariably insignificant. These results suggest that hot temperatures only affect significantly market activity on the day they occur and not on the days that follow. In other terms, the negative impact of extreme heat on market activity vanishes on subsequent days when temperatures return to normal levels.

\section{Conclusion}

Is market activity sensitive to excessive heat? If so, to what extent does market activity decrease on days with hot weather? We provide answers to these important questions by examining abnormal trading volumes on the French stock market on days with severe heat in Paris over the period 1995-2019. After controlling for seasonal effects such as the "summer holiday" effect, our results show that market activity falls significantly when the temperatures in Paris exceed $30^{\circ} \mathrm{C}$ $\left(86^{\circ} \mathrm{F}\right)$. The potential mechanism driving these findings is that extreme heat increases the tiredness, the bad mood and the distraction of French investors, which therefore diminishes their propensity to trade securities.

These findings are consistent with the labor economics literature demonstrating that excessive outdoor temperature tend to deteriorate the cognitive performance (e.g., Cho, 2017; Park, 2016) and the emotional state of indoor workers (e.g., Heyes and Saberian, 2019). They also corroborate the results of previous research work on behavioral finance that emphasized the importance of 
weather in understanding investor decisions. Although these previous works revealed the existence of a "sunshine" effect (Hirshleifer and Shumway, 2003); a "daylight duration" effect (Kamstra et al., 2003), a “cloud" effect (Saunders, 1993), a "humidity" effect (Yoon and Kang, 2009), or a "air pollution" effect (Heyes et al., 2016), our research enriches this body of literature by demonstrating the presence of a "hot weather" effect on financial markets.

Being careful to not over-interpret our results, we are convinced that they are relevant not only for academics but also for managers of financial companies and policy makers. Managers of financial firms could implement policies to raise the comfort, and therefore the productivity, of their traders when temperatures rise above a certain threshold. First, it is well known that financial companies often impose a particularly strict dress code. For instance, managers of financial institutions could allow their employees to dress casually at the workplace on days when the temperature is excessively high. Second, companies whose offices are not air-conditioned could allow their employees to telework. This would eventually allow investors to work more comfortably without having to deal with public transportation and offices that are not airconditioned. Third, these financial institutions could also ameliorate the working conditions of their employees by installing air conditioning. In this context, traditional air conditioners should be avoided as they tend to aggravate environmental and weather problems. Indeed, in case of leakage, air conditioners that rely on chlorofluorocarbons (CFC) are extremely harmful for the ozone layer. In addition, by releasing hot air to the outside, they eventually amplify the external temperature. Finally, they consume a lot of electricity, especially mobile air conditioners with low efficiency. These companies would then benefit from using energy-efficient solutions that avoid CFC. In this sense, policy makers should thus encourage companies to develop eco-friendly airconditioning systems and to select environmentally efficient building designs (e.g., Pandit and Laband, 2010). 
Even though our results clearly reveal a decline in trading volume when temperatures in Paris exceed $30^{\circ} \mathrm{C}\left(86^{\circ} \mathrm{F}\right)$, we acknowledge several limitations of our research that should be considered in the future. First, although we mention three possible channels that may explain the impact of excessively high temperatures on the trading volume (tiredness, bad mood, and distraction), our econometric analyses in its current form do not make it possible to test the relevance and the importance of each of them. An interesting direction for further research is therefore to explicitly and distinctly identify the precise mechanisms behind the decline of trading volume during extreme heats, for example, by performing experiments or conducting surveys. Second, considering only the daily temperatures in Paris as a main determinant of trading volumes on the French stock market is a quite restrictive approach. Indeed, the French securities can be traded by investors located anywhere in France and in the world, where temperatures may be lower or air conditioning more widely installed. Although we have shown that these elements are less of a concern in the French context, it would also be worth exploring the effects of extremely high temperatures on investor activity at the investor level and not at the market level. Third, while our empirical analysis refers to the French stock market, an extension of our study to other countries would certainly be instructive. Finally, although trading volume is a good proxy for investor activity, a better understanding of changes in volume does not offer much insight in terms of trading strategies. In this context, it could be interesting to examine the effects of high temperatures on stock returns and volatility. 


\section{References}

Abd-Elfattah, H. M., Abdelazeim, F. H., \& Elshennawy, S. (2015). Physical and cognitive consequences of fatigue: A review. Journal of advanced research, 6(3), 351-358.

Addoum, J. M., Ng, D. T., \& Ortiz-Bobea, A. (2019). Temperature shocks and earning news. Review of Financial Studies.

Anderson, C. A. (1987). Temperature and aggression: Effects on quarterly, yearly, and city rates of violent and nonviolent crime. Journal of personality and social psychology, 52(6), 1161.

Bassi, A., Colacito, R., and Fulghieri, P. (2013). 'O sole mio': An experimental analysis of weather and risk attitudes in financial decisions. Review of Financial Studies 26, 1824-1852.

Baylis, P. (2015). Temperature and temperament: Evidence from a billion tweets. Energy Institute at HAAS working paper.

Brown, S. J., and Warner, J. B. (1985). Using daily stock returns: The case of event studies. Journal of Financial Economics 14 (1), 3-31.

Cao, M., and Wei, J. (2005). Stock market returns: A note on temperature anomaly. Journal of Banking \& Finance 29 (6), 1559-1573.

Capelle-Blancard, G., and Laguna, M. A. (2010). How does the stock market respond to chemical disasters? Journal of Environmental Economics and Management 59 (2), 192-205.

Capelle-Blancard, G., Crifo, P., Diaye, M. A., Oueghlissi, R., \& Scholtens, B. (2019). Sovereign bond yield spreads and sustainability: An empirical analysis of OECD countries. Journal of Banking \& Finance, 98, 156-169.

Chen, X., and Yang, L. (2019). Temperature and industrial output: firm-level evidence from China. Journal of Environmental Economics and Management 95, 257-274.

Cho, H. (2017). The effects of summer heat on academic achievement: A cohort analysis. Journal of Environmental Economics and Management 83, 185-196. 
Fishe, R. P., Gosnell, T. F., \& Lasser, D. J. (1993). Good news, bad news, volume, and the Monday effect. Journal of Business Finance \& Accounting, 20(6), 881-892.

Foster, F. D., and Viswanathan, S. (1993). Variations in trading volume, return volatility, and trading costs: Evidence on recent price formation models. The Journal of Finance 48, 187-211.

Goetzmann, W.N., Kim, D., Kumar, A., and Wang, Q. (2014). Weather-induced mood, institutional investors, and stock returns. Review of Financial Studies 28, 73-111.

Graff Zivin, J., and Neidell, M. (2012). The impact of pollution on worker productivity. American Economic Review 102, 3652-3673.

Graff Zivin, J., Hsiang, S. M., \& Neidell, M. (2018). Temperature and human capital in the short and long run. Journal of the Association of Environmental and Resource Economists, 5(1), 77-105.

Gupta, S., \& Goldar, B. (2005). Do stock markets penalize environment-unfriendly behaviour? Evidence from India. Ecological economics, 52(1), 81-95.

Gutsche, G., \& Ziegler, A. (2019). Which private investors are willing to pay for sustainable investments? Empirical evidence from stated choice experiments. Journal of Banking \& Finance, $102,193-214$.

Heyes, A., Neidell, M., \& Saberian, S. (2016). The effect of air pollution on investor behavior: evidence from the S\&P 500 (No. w22753). National Bureau of Economic Research.

Heyes, A., \& Saberian, S. (2019). Temperature and decisions: evidence from 207,000 court cases. American Economic Journal: Applied Economics, 11(2), 238-65.

Hirshleifer, D., and Shumway, T. (2003). Good day sunshine: Stock returns and the weather. Journal of Finance 58, 1009-1032.

Hou, J., Shi, W., \& Sun, J. (2019). Stock Returns, weather, and air conditioning. PloS one, 14(7).

Hsiang, S. M., Burke, M., \& Miguel, E. (2013). Quantifying the influence of climate on human conflict. Science, 341(6151).

Hübler, M., Klepper, G., \& Peterson, S. (2008). Costs of climate change: the effects of rising temperatures on health and productivity in Germany. Ecological Economics, 68(1-2), 381-393.

ILO, 2019, Working on a warmer planet: The impact of heat stress on labor productivity and decent work. 
Kamstra, M.J., Kramer L.A., and Levi M.D. (2003). Winter blues: A SAD stock market cycle. American Economic Review 93, 324-343.

Kussel, G. (2018). Adaptation to Climate Variability: Evidence for German Households. Ecological Economics, 143, 1-9.

Makridis, C. (2018). Can you feel the heat? Extreme temperatures, stock returns, and economic sentiment. Extreme Temperatures, Stock Returns, and Economic Sentiment (December 26, 2018).

Otrachshenko, V., Popova, O., \& Solomin, P. (2017). Health consequences of the Russian weather. Ecological Economics, 132, 290-306.

Pandit, R., \& Laband, D. N. (2010). Energy savings from tree shade. Ecological Economics, 69(6), 1324-1329.

Park, J. (2016). Temperature, test scores, and educational attainment. Unpublished working paper.

Peress, J., \& Schmidt, D. (2020). Glued to the TV: Distracted noise traders and stock market liquidity. The Journal of Finance, 75(2), 1083-1133.

Saunders, E.M. (1993). Stock prices and wall street weather. American Economic Review 83, $1337-1345$.

Somanathan, E., Somanathan, R., Sudarshan, A., \& Tewari, M. (2015). The impact of temperature on productivity and labor supply: Evidence from Indian manufacturing. Indian Statistical Institute: New Delhi, India.

Takeda, F., \& Tomozawa, T. (2008). A change in market responses to the environmental management ranking in Japan. Ecological Economics, 67(3), 465-472.

Yoon, S.M., and Kang, S.H. (2009). Weather effects on returns: Evidence from the Korean stock market. Physica A: Statistical Mechanics and Its Applications, 388 (5), 682-690.

Zander, K. K., Botzen, W. J., Oppermann, E., Kjellstrom, T., \& Garnett, S. T. (2015). Heat stress causes substantial labour productivity loss in Australia. Nature Climate Change, 5(7), 647651. 
Table 1

Descriptive statistics, January 1995-December 2019

\begin{tabular}{|c|c|c|c|c|c|}
\hline \multirow{2}{*}{ Panel A } & \multicolumn{5}{|c|}{ Number of hot days } \\
\hline & $>30^{\circ} \mathrm{C}$ & $>31{ }^{\circ} \mathrm{C}$ & $>32{ }^{\circ} \mathrm{C}$ & $>33^{\circ} \mathrm{C}$ & $>34^{\circ} \mathrm{C}$ \\
\hline 1995-1999 & 65 & 51 & 30 & 18 & 9 \\
\hline 2000-2004 & 69 & 48 & 27 & 24 & 18 \\
\hline $2005-2009$ & 67 & 48 & 32 & 15 & 7 \\
\hline 2010-2014 & 44 & 28 & 16 & 10 & 6 \\
\hline 2015-2019 & 107 & 76 & 53 & 39 & 26 \\
\hline Whole period & 352 & 251 & 158 & 106 & 66 \\
\hline \multirow{2}{*}{ Panel B } & \multicolumn{5}{|c|}{ Daily maximum temperatures } \\
\hline & $\mathrm{N}$ & Mean & S.d. & Min. & Max. \\
\hline 1995-1999 & 1,724 & 16.39 & 7.94 & -6.10 & 37.70 \\
\hline 2000-2004 & 1,780 & 16.73 & 7.75 & -3.80 & 40.00 \\
\hline 2005-2009 & 1,782 & 16.74 & 7.82 & -1.60 & 36.70 \\
\hline 2010-2014 & 1,785 & 16.48 & 7.71 & -3.10 & 38.20 \\
\hline 2015-2019 & 1,782 & 17.39 & 8.03 & -2.6 & 41.90 \\
\hline Whole period & 8,853 & 16.75 & 7.86 & -6.1 & 41.9 \\
\hline \multirow{2}{*}{ Panel C } & \multicolumn{5}{|c|}{ Daily trading volumes SBF250 } \\
\hline & $\mathrm{N}$ & Mean & S.d. & Min. & Max. \\
\hline 1995-1999 & 1,245 & $20,857,175$ & $29,212,789$ & $3,246,018$ & $690,627,800$ \\
\hline $2000-2004$ & 1,276 & $133,781,361$ & $72,465,959$ & $16,547,990$ & $612,610,500$ \\
\hline $2005-2009$ & 1,279 & $210,508,288$ & $73,294,041$ & $30,394,040$ & $886,258,200$ \\
\hline 2010-2014 & 1,281 & $191,142,169$ & $56,896,117$ & $18,963,000$ & $530,111,600$ \\
\hline 2015-2019 & 1,278 & $172,623,490$ & $57,028,131$ & $28,862,800$ & $717,639,400$ \\
\hline Whole period & 6,359 & $146,588,995$ & $90,438,266$ & $3,246,018$ & $886,258,200$ \\
\hline
\end{tabular}

Note: Panels A and B present descriptive statistics of the number of days with severe heat and maximum daily temperatures in Paris for the period January 1, 1995, to December 31, 2019. These two panels include all calendar days, i.e., all trading and non-trading days. Panel $\mathrm{C}$ presents descriptive statistics of daily trading volumes for the SBF250 stock index, which is composed of the 250 French stocks with the highest market capitalization. The daily trading volume is the number of shares traded on a single day. In Panel C, non-trading days are excluded. 


\section{Table 2}

Relationship between temperature bins and deseasonalized trading volumes on the SBF250 stock index

\begin{tabular}{|c|c|c|c|c|c|}
\hline Period & Indicator & Bin 1 & $\operatorname{Bin} 2$ & Bin 3 & Bin 4 \\
\hline \multirow{2}{*}{ Whole period } & $\%$ diff. $(4, i)$ & $-6 \%$ & $-9 \%$ & $-6 \%$ & - \\
\hline & $\mathrm{z}$-score $(4, \mathrm{i})$ & $-3.10 * * *$ & $-5.72 * * *$ & $-4.21 * * *$ & - \\
\hline \multirow{2}{*}{ 1995-1999 } & $\%$ diff. $(4, i)$ & $-2 \%$ & $-8 \%$ & $-4 \%$ & - \\
\hline & z-score $(4, i)$ & -0.56 & $-2.41 * * *$ & -1.47 & - \\
\hline \multirow{2}{*}{ 2000-2004 } & $\%$ diff. $(4, i)$ & $4 \%$ & $-2 \%$ & $-3 \%$ & - \\
\hline & $\mathrm{z}$-score $(4, \mathrm{i})$ & 1.04 & -0.40 & -0.80 & - \\
\hline \multirow{2}{*}{ 2005-2009 } & $\%$ diff. $(4, \mathrm{i})$ & $-5 \%$ & $-9 \%$ & $-5 \%$ & - \\
\hline & z-score $(4, i)$ & -1.47 & $-3.32 * * *$ & $-1.82 *$ & - \\
\hline \multirow{2}{*}{ 2010-2014 } & $\%$ diff. $(4, \mathrm{i})$ & $0 \%$ & $-2 \%$ & $-4 \%$ & - \\
\hline & $\mathrm{z}$-score $(4, \mathrm{i})$ & 0.02 & -0.78 & $-1.76^{*}$ & - \\
\hline \multirow{2}{*}{ 2015-2019 } & $\%$ diff. $(4, i)$ & $-15 \%$ & $-9 \%$ & $-4 \%$ & - \\
\hline & $\mathrm{z}$-score $(4, \mathrm{i})$ & $-5.65 * * *$ & $-3.69 * * *$ & $-1.80^{*}$ & - \\
\hline
\end{tabular}

Note: This Table reports the difference in percentage (\% diff. $(4, \mathrm{i}))$ between the average deseasonalized trading volume for bin $\mathrm{i}(\mathrm{i}=\{1,2,3\})$ and bin 4 (i.e., the bin that contains the highest temperatures) with the corresponding z-score (z-score $(4, i))$. The results are reported for each half-decades of our sample (i.e., 1995-1999, 2000-2004, 2005-2009, 2010-2014, and 2015-2019). Whole period: January 1, 1995-December 31, 2019. * $\mathrm{p}<.1, * * \mathrm{p}<.05$, and $* * * \mathrm{p}<.01$. Two-tailed tests. 


\section{Table 3}

Relationship between temperature bins and deseasonalized trading volumes on the CAC40 stock index

\begin{tabular}{|c|c|c|c|c|c|}
\hline Period & Indicator & Bin 1 & $\operatorname{Bin} 2$ & Bin 3 & Bin 4 \\
\hline \multirow{2}{*}{ Whole period } & $\%$ diff. $(4, i)$ & $-8 \%$ & $-8 \%$ & $-7 \%$ & - \\
\hline & z-score $(4, \mathrm{i})$ & $-4.05 * * *$ & $-5.01 * * *$ & $-4.13 * * *$ & - \\
\hline \multirow{2}{*}{ 1995-1999 } & $\%$ diff. $(4, i)$ & $-15 \%$ & $-15 \%$ & $-10 \%$ & - \\
\hline & z-score $(4, i)$ & $-2.38 * * *$ & $-2.56 * * *$ & $-1.70 * *$ & - \\
\hline \multirow{2}{*}{ 2000-2004 } & $\%$ diff. $(4, i)$ & $-3 \%$ & $-4 \%$ & $-8 \%$ & - \\
\hline & $\mathrm{z}$-score $(4, \mathrm{i})$ & -0.69 & -1.27 & $-2.35 * * *$ & - \\
\hline \multirow{2}{*}{ 2005-2009 } & $\%$ diff. $(4, \mathrm{i})$ & $-3 \%$ & $-6 \%$ & $-3 \%$ & - \\
\hline & z-score $(4, i)$ & -0.89 & $-2.03 * *$ & -0.98 & - \\
\hline \multirow{2}{*}{ 2010-2014 } & $\%$ diff. $(4, \mathrm{i})$ & $0 \%$ & $-1 \%$ & $-3 \%$ & - \\
\hline & $\mathrm{z}$-score $(4, \mathrm{i})$ & 0.08 & -0.30 & -0.70 & - \\
\hline \multirow{2}{*}{ 2015-2019 } & $\%$ diff. $(4, i)$ & $-18 \%$ & $-12 \%$ & $-7 \%$ & - \\
\hline & $\mathrm{z}$-score $(4, \mathrm{i})$ & $-5.02 * * *$ & $-4.63 * * *$ & $-2.72 * * *$ & - \\
\hline
\end{tabular}

Note: This Table reports the difference in percentage $(\%$ diff. $(4, \mathrm{i}))$ between the average deseasonalized trading volume for bin $\mathrm{i}(\mathrm{i}=\{1,2,3\})$ and bin 4 (i.e., the bin that contains the highest temperatures) with the corresponding z-score (z-score $(4, \mathrm{i})$ ). The results are reported for each half-decades of our sample (i.e., 1995-1999, 2000-2004, 2005-2009, 2010-2014, and 2015-2019). Whole period: January 1, 1995-December 31, 2019. * $\mathrm{p}<.1, * * \mathrm{p}<.05$, and $* * * \mathrm{p}<.01$. Two-tailed tests. 


\section{Table 4}

Abnormal average deseasonalized trading volumes on the SBF250 stock index on days with severe heat

\begin{tabular}{|c|c|c|c|c|c|}
\hline Temperature & $\mathrm{N}$ & AAVOLUME & z-stat & Positive: Negative & Sign z-stat \\
\hline \multicolumn{6}{|c|}{ Panel A: estimation window $[-200,-1]$} \\
\hline$>30^{\circ} \mathrm{C}$ & 233 & $-7 \%$ & $-4.94 * * *$ & $89: 144$ & $-3.60 * * *$ \\
\hline$>31{ }^{\circ} \mathrm{C}$ & 167 & $-8 \%$ & $-4.85 * * *$ & 59:108 & $-3.79 * * *$ \\
\hline$>32{ }^{\circ} \mathrm{C}$ & 108 & $-6 \%$ & $-2.74 * * *$ & $44: 64$ & $-1.92 *$ \\
\hline$>33{ }^{\circ} \mathrm{C}$ & 78 & $-8 \%$ & $-2.87 * * *$ & $31: 47$ & $-1.81 *$ \\
\hline$>34^{\circ} \mathrm{C}$ & 51 & $-10 \%$ & $-2.98 * * *$ & $18: 33$ & $-2.10 * *$ \\
\hline \multicolumn{6}{|c|}{ Panel B: estimation window $[-100,-1]$} \\
\hline$>30{ }^{\circ} \mathrm{C}$ & 233 & $-6 \%$ & $-4.47 * * *$ & $88: 145$ & $-3.73 * * *$ \\
\hline$>31{ }^{\circ} \mathrm{C}$ & 167 & $-8 \%$ & $-4.72 * * *$ & 59:108 & $-3.79 * * *$ \\
\hline$>32{ }^{\circ} \mathrm{C}$ & 108 & $-7 \%$ & $-2.85 * * *$ & $44: 64$ & $-1.92^{*}$ \\
\hline$>33{ }^{\circ} \mathrm{C}$ & 78 & $-7 \%$ & $-2.78 * * *$ & $32: 46$ & -1.58 \\
\hline$>34^{\circ} \mathrm{C}$ & 51 & $-10 \%$ & $-2.83 * * *$ & $19: 32$ & $-1.82 *$ \\
\hline \multicolumn{6}{|c|}{ Panel C: estimation window $[-30,-1]$} \\
\hline$>30{ }^{\circ} \mathrm{C}$ & 233 & $-5 \%$ & $-3.50 * * *$ & $86: 147$ & $-3.99 * * *$ \\
\hline$>31{ }^{\circ} \mathrm{C}$ & 167 & $-6 \%$ & $-3.59 * * *$ & 61:106 & $-3.48 * * *$ \\
\hline$>32{ }^{\circ} \mathrm{C}$ & 108 & $-4 \%$ & $-1.83^{*}$ & $42: 66$ & $-2.30 * *$ \\
\hline$>33{ }^{\circ} \mathrm{C}$ & 78 & $-4 \%$ & -1.42 & $29: 49$ & $-2.26 * *$ \\
\hline$>34^{\circ} \mathrm{C}$ & 51 & $-5 \%$ & -1.46 & 21:30 & -1.26 \\
\hline \multicolumn{6}{|c|}{ Panel D: estimation window $[-15,-1]$} \\
\hline$>30^{\circ} \mathrm{C}$ & 233 & $-4 \%$ & $-3.00 * * *$ & 95:138 & $-2.81 * * *$ \\
\hline$>31{ }^{\circ} \mathrm{C}$ & 167 & $-5 \%$ & $-2.86^{* * *}$ & $67: 100$ & $-2.55^{* * *}$ \\
\hline$>32{ }^{\circ} \mathrm{C}$ & 108 & $-4 \%$ & -1.45 & $46: 62$ & -1.53 \\
\hline$>33{ }^{\circ} \mathrm{C}$ & 78 & $-4 \%$ & -1.22 & $32: 46$ & -1.58 \\
\hline$>34^{\circ} \mathrm{C}$ & 51 & $-6 \%$ & -1.48 & $20: 31$ & -1.54 \\
\hline
\end{tabular}

Note: This table presents the abnormal average trading volumes (AAVOLUME) on the SBF250 stock index for days when the maximum temperature exceeds $30^{\circ} \mathrm{C}\left(86^{\circ} \mathrm{F}\right), 31^{\circ} \mathrm{C}\left(87.8^{\circ} \mathrm{F}\right), 32^{\circ} \mathrm{C}\left(89.6^{\circ} \mathrm{F}\right), 33^{\circ} \mathrm{C}\left(91.4^{\circ} \mathrm{F}\right)$, and $34^{\circ} \mathrm{C}$ $\left(93.2^{\circ} \mathrm{F}\right)$, respectively. AAVOLUME is expressed as percentage and its calculation is based on deseasonalized trading volume variable taken in logarithm. The column "Positive: Negative" counts of positive and negative individual abnormal deseasonalized trading volumes. Panel A shows these results when we use the time interval [-200, -1] to compute the theoretical deseasonalized trading volumes, while Panels B, C, and D display these results for the estimation window [-100, -1], [-30, -1], and [-15, -1], respectively. Period: January 1, 1995-December 31, 2019.* p $<.1, * * \mathrm{p}<.05$, and $* * * \mathrm{p}<.01$. Two-tailed tests. 
Table 5

Abnormal average deseasonalized trading volumes on the CAC40 stock index on days with severe heat

\begin{tabular}{|c|c|c|c|c|c|}
\hline Temperature & $\mathrm{N}$ & AAVOLUME & Z-stat & Positive: Negative & Sign z-stat \\
\hline \multicolumn{6}{|c|}{ Panel A: estimation window $[-200,-1]$} \\
\hline$>30^{\circ} \mathrm{C}$ & 233 & $-8 \%$ & $-4.98 * * *$ & $78: 155$ & $-5.04 * * *$ \\
\hline$>31{ }^{\circ} \mathrm{C}$ & 167 & $-8 \%$ & $-4.48 * * *$ & $54: 113$ & $-4.56 * * *$ \\
\hline$>32{ }^{\circ} \mathrm{C}$ & 108 & $-8 \%$ & $-3.47 * * *$ & $33: 75$ & $-4.04 * * *$ \\
\hline$>33{ }^{\circ} \mathrm{C}$ & 78 & $-9 \%$ & $-3.45 * * *$ & $21: 57$ & $-4.07 * * *$ \\
\hline$>34{ }^{\circ} \mathrm{C}$ & 51 & $-11 \%$ & $-3.53 * * *$ & $13: 38$ & $-3.50 * * *$ \\
\hline \multicolumn{6}{|c|}{ Panel B: estimation window $[-100,-1]$} \\
\hline$>30{ }^{\circ} \mathrm{C}$ & 233 & $-8 \%$ & $-4.61 * * *$ & $80: 153$ & $-4.78 * * *$ \\
\hline$>31{ }^{\circ} \mathrm{C}$ & 167 & $-8 \%$ & $-4.24 * * *$ & $56: 111$ & $-4.25 * * *$ \\
\hline$>32{ }^{\circ} \mathrm{C}$ & 108 & $-8 \%$ & $-3.48 * * *$ & $33: 75$ & $-4.04 * * *$ \\
\hline$>33{ }^{\circ} \mathrm{C}$ & 78 & $-8 \%$ & $-3.20 * * *$ & $22: 56$ & $-3.84 * * *$ \\
\hline$>34{ }^{\circ} \mathrm{C}$ & 51 & $-10 \%$ & $-3.20 * * *$ & $14: 37$ & $-3.22 * * *$ \\
\hline \multicolumn{6}{|c|}{ Panel C: estimation window $[-30,-1]$} \\
\hline$>30{ }^{\circ} \mathrm{C}$ & 233 & $-6 \%$ & $-3.51 * * *$ & $87: 146$ & $-3.86 * * *$ \\
\hline$>31{ }^{\circ} \mathrm{C}$ & 167 & $-6 \%$ & $-3.15 * * *$ & 60:107 & $-3.63 * * *$ \\
\hline$>32{ }^{\circ} \mathrm{C}$ & 108 & $-5 \%$ & $-1.96 * *$ & $40: 68$ & $-2.69 * * *$ \\
\hline$>33{ }^{\circ} \mathrm{C}$ & 78 & $-4 \%$ & -1.43 & $27: 51$ & $-2.71 * * *$ \\
\hline$>34{ }^{\circ} \mathrm{C}$ & 51 & $-5 \%$ & -1.33 & $19: 32$ & $-1.82 *$ \\
\hline \multicolumn{6}{|c|}{ Panel D: estimation window $[-15,-1]$} \\
\hline$>30^{\circ} \mathrm{C}$ & 233 & $-5 \%$ & $-2.61 * * *$ & 95:138 & $-2.81 * * *$ \\
\hline$>31{ }^{\circ} \mathrm{C}$ & 167 & $-5 \%$ & $-2.33 * * *$ & $68: 99$ & $-2.39 * * *$ \\
\hline$>32{ }^{\circ} \mathrm{C}$ & 108 & $-3 \%$ & -1.17 & $47: 61$ & -1.34 \\
\hline$>33{ }^{\circ} \mathrm{C}$ & 78 & $-3 \%$ & -0.90 & $33: 45$ & -1.35 \\
\hline$>34{ }^{\circ} \mathrm{C}$ & 51 & $-4 \%$ & -0.98 & $21: 30$ & -1.26 \\
\hline
\end{tabular}

Note: This table presents the abnormal average trading volumes (AAVOLUME) on the CAC40 stock index for days when the maximum temperature exceeds $30^{\circ} \mathrm{C}\left(86^{\circ} \mathrm{F}\right), 31^{\circ} \mathrm{C}\left(87.8^{\circ} \mathrm{F}\right), 32^{\circ} \mathrm{C}\left(89.6^{\circ} \mathrm{F}\right), 33^{\circ} \mathrm{C}\left(91.4^{\circ} \mathrm{F}\right)$, and $34^{\circ} \mathrm{C}$ $\left(93.2^{\circ} \mathrm{F}\right)$, respectively. AAVOLUME is expressed as percentage and its calculation is based on deseasonalized trading volume variable taken in logarithm. The column "Positive: Negative" counts of positive and negative individual abnormal deseasonalized trading volumes. Panel A shows these results when we use the time interval [-200, -1] to compute the theoretical deseasonalized trading volumes, while Panels B, C, and D display these results for the estimation window [-100, -1], [-30, -1], and [-15, -1], respectively. Period: January 1, 1995-December 31, 2019. * p $<.1, * * \mathrm{p}<.05$, and $* * * \mathrm{p}<.01$. Two-tailed tests. 


\section{Table 6}

Abnormal average deseasonalized trading volumes on the SBF250 index during the summer holidays

\begin{tabular}{lcccc}
\hline \multicolumn{5}{c}{ Panel A: days $>30^{\circ} \mathrm{C}$ during the French summer vacations } \\
\hline Estimation windows & {$[-200,-1]$} & {$[-100,-1]$} & {$[-30,-1]$} & {$[-15,-1]$} \\
\hline $\mathrm{N}$ & 161 & 161 & 161 & 161 \\
AAVOLUME & $-6 \%$ & $-6 \%$ & $-4 \%$ & $-3 \%$ \\
Z-stat & $-3.80^{* * *}$ & $-3.35^{* * *}$ & $-2.47^{* * *}$ & $-1.74^{*}$ \\
Positive: Negative & $62: 99$ & $65: 96$ & $62: 99$ & $69: 92$ \\
Sign z-stat & $-2.91 * * *$ & $-2.44^{* * *}$ & $-2.91 * * *$ & $-1.81^{*}$ \\
\hline & Panel B: days $<30^{\circ} \mathrm{C}$ during the French summer vacations & \\
\hline Estimation windows & {$[-200,-1]$} & {$[-100,-1]$} & {$[-30,-1]$} & {$[-15,-1]$} \\
\hline N & 890 & 890 & 890 & 890 \\
AAVOLUME & $0 \%$ & $1 \%$ & $-1 \%$ & $-1 \%$ \\
z-stat & 0.17 & 0.62 & -0.57 & -1.01 \\
Positive: Negative & $420: 470$ & $424: 466$ & $407: 483$ & $402: 488$ \\
Sign z-stat & $-1.67 *$ & -1.40 & $-2.54 * *$ & $-2.88 * *$ \\
\hline
\end{tabular}

Note: This table presents the abnormal average trading volumes (AAVOLUMEs) on the SBF250 stock index for days where the maximum temperature is above $30^{\circ} \mathrm{C}\left(86^{\circ} \mathrm{F}\right)\left(\right.$ Panel A) and below $30^{\circ} \mathrm{C}$ (Panel B) during the July-August period. AAVOLUME is expressed as percentage and its calculation is based on deseasonalized trading volume variable taken in logarithm. "Positive: Negative" counts of positive and negative individual abnormal deseasonalized trading volumes. The second column shows these results when we use the time interval $[-200,-1]$ to compute the theoretical deseasonalized trading volumes, while the third, the fourth and the fifth columns display these results for the estimation windows [-100, -1], [-30, -1]), and [-15, -1], respectively. Period: January 1, 1995-December 31, 2019. $* \mathrm{p}<.1, * * \mathrm{p}<.05$, and $* * * \mathrm{p}<.01$. Two-tailed tests. 


\section{Table 7}

Abnormal average deseasonalized trading volumes on French stock indices on days with severe heat across half-decades

\begin{tabular}{|c|c|c|c|c|c|}
\hline Half-decades & $\mathrm{N}$ & AAVOLUME & z-stat & Positive: Negative & Sign z-stat \\
\hline \multicolumn{6}{|c|}{ Panel A: SBF250 stock index } \\
\hline 1995-1999 & 39 & $-9 \%$ & $-2.43 * * *$ & $14: 25$ & $-1.71 *$ \\
\hline 2000-2004 & 48 & $-5 \%$ & -1.34 & $20: 28$ & -1.15 \\
\hline 2005-2009 & 51 & $-9 \%$ & $-2.34 * * *$ & $18: 33$ & $-2.10 * *$ \\
\hline 2010-2014 & 30 & $-8 \%$ & $-2.20 * *$ & $10: 20$ & $-1.82 *$ \\
\hline 2015-2019 & 77 & $-11 \%$ & $-5.14 * * *$ & $25: 52$ & $-3.07 * * *$ \\
\hline \multicolumn{6}{|c|}{ Panel B: CAC40 stock index } \\
\hline 1995-1999 & 39 & $-8 \%$ & -1.57 & $14: 25$ & -1.40 \\
\hline 2000-2004 & 48 & $-5 \%$ & -1.16 & $21: 27$ & -0.86 \\
\hline 2005-2009 & 51 & $-5 \%$ & $-1.64 *$ & $19: 32$ & $-1.82 *$ \\
\hline 2010-2014 & 30 & $-8 \%$ & $-2.16^{* *}$ & $7: 23$ & $-2.92 * * *$ \\
\hline 2015-2019 & 77 & $-11 \%$ & $-4.21 * * *$ & $21: 56$ & $-3.98 * * *$ \\
\hline
\end{tabular}

Note: This table presents the abnormal average trading volumes (AAVOLUME) on the French stock indices for days when the maximum temperature exceeds $30^{\circ} \mathrm{C}\left(86^{\circ} \mathrm{F}\right)$ across half-decades. AAVOLUME is expressed as percentage and its calculation is based on deseasonalized trading volume variable taken in logarithm. "Positive: Negative" counts of positive and negative individual abnormal deseasonalized trading volumes. The table shows these results when we use the time interval $[-100,-1]$ to compute the theoretical deseasonalized trading volumes. Panel A reports the results for the SBF250 stock index, while Panel B displays the results for the CAC40 stock index. $* \mathrm{p}<.1, * * \mathrm{p}<.05$, and $* * * \mathrm{p}<.01$. Two-tailed tests. 


\section{Table 8}

Days with severe heat and deseasonalized trading volumes on the SBF250 stock index: time-series regressions

\begin{tabular}{|c|c|c|}
\hline SBF250 stock index & Model 1 & Model 2 \\
\hline Constant & $\begin{array}{c}0.01 \\
(0.66)\end{array}$ & $\begin{array}{c}0.01 \\
(0.21)\end{array}$ \\
\hline$D A Y S>30^{\circ} C_{t}$ & $\begin{array}{c}-0.07 * * * \\
(0.00)\end{array}$ & $\begin{array}{c}-0.05^{* * * *} \\
(0.00)\end{array}$ \\
\hline $\operatorname{Ln}\left(V O L U M E_{S B F 250, t-1}\right)$ & - & $\begin{array}{c}0.42 * * * \\
(0.00)\end{array}$ \\
\hline $\operatorname{Ln}\left(V O L U M E_{S B F 250, t-2}\right)$ & - & $\begin{array}{c}0.09 * * * \\
(0.00)\end{array}$ \\
\hline $\operatorname{Ln}\left(V O L U M E_{M S C I} U S A, t\right)$ & - & $\begin{array}{c}0.44 * * * \\
(0.00)\end{array}$ \\
\hline VOLATILITY $_{S B F 250, t}$ & - & $\begin{array}{l}-0.76 \\
(0.16)\end{array}$ \\
\hline $\mathrm{R}^{2}$ & 0.01 & 0.45 \\
\hline $\mathrm{N}$ & 6,522 & 6,501 \\
\hline
\end{tabular}

Note: This table presents the effects of days with severe heat $\left(D A Y S>30^{\circ} C_{t}\right)$ on the deseasonalized trading volumes on the SBF250 stock index using OLS regressions. The dependent variable, namely the daily deseasonalized trading volumes on the SBF250 stock index $\left(\operatorname{Ln}\left(V O L U M E_{S B F 250, t}\right)\right)$, are expressed in logarithmic value. The independent variable of interest $D A Y S>30^{\circ} \mathrm{C}{ }_{t}$ is a dummy variable which equals one when the maximum temperature exceeds $30^{\circ} \mathrm{C}\left(86^{\circ} \mathrm{F}\right)$ during the trading day $\mathrm{t}$ and equals zero otherwise. $\operatorname{VOLATILITY}_{S B F 250, t}$ denotes the conditional volatility on the SBF250 stock index obtained from a GARCH(1,1) model in day t. The coefficients and the associated p-values in parentheses are estimated using heteroskedasticity-robust standard errors. For cases where parameters are not estimated, the cells contain a dash (一). Period: January 1, 1995-December $31,2019 .{ }^{*} \mathrm{p}<.1,{ }^{* *} \mathrm{p}<.05$, and $* * * \mathrm{p}$ $<.01$. 


\section{Table 9}

Days with severe heat and deseasonalized trading volumes on the CAC40 stock index: time-series regressions

\begin{tabular}{|c|c|c|}
\hline CAC40 stock index & Model 1 & Model 2 \\
\hline Constant & $\begin{array}{c}0.01 \\
(0.28)\end{array}$ & $\begin{array}{c}0.00 \\
(0.94)\end{array}$ \\
\hline$D A Y S>30^{\circ} C_{t}$ & $\begin{array}{c}-0.07 * * * \\
(0.00)\end{array}$ & $\begin{array}{c}-0.05 * * * \\
(0.00)\end{array}$ \\
\hline $\operatorname{Ln}\left(V O L U M E_{C A C 40, t-1}\right)$ & - & $\begin{array}{c}0.37 * * * \\
(0.00)\end{array}$ \\
\hline $\operatorname{Ln}\left(V O L U M E_{C A C 40, t-2}\right)$ & - & $\begin{array}{c}0.11 * * * \\
(0.00)\end{array}$ \\
\hline $\operatorname{Ln}\left(V O L U M E_{M S C I U S A, t}\right)$ & - & $\begin{array}{c}0.55^{* * * *} \\
(0.00)\end{array}$ \\
\hline$V_{O L A T I L I T Y} Y_{C A C 40, t}$ & - & $\begin{array}{c}0.07 \\
(0.89)\end{array}$ \\
\hline $\mathrm{R}^{2}$ & 0.01 & 0.92 \\
\hline $\mathrm{N}$ & 6,522 & 6,501 \\
\hline
\end{tabular}

Note: This table presents the effects of days with severe heat $\left(D A Y S>30^{\circ} C_{t}\right)$ on the deseasonalized trading volumes on the CAC40 stock index using OLS regressions. The dependent variable, namely the daily deseasonalized trading volumes on the CAC40 stock index $\left(\operatorname{Ln}\left(V_{O L U M} E_{C A C 40, t}\right)\right)$, are expressed in logarithmic value. The independent variable of interest $D A Y S>30^{\circ} \mathrm{C}{ }_{t}$ is a dummy variable which equals one when the maximum temperature exceeds $30^{\circ} \mathrm{C}\left(86^{\circ} \mathrm{F}\right)$ during the trading day $\mathrm{t}$ and equals zero otherwise. $\operatorname{VOLATILITY}_{C A C 40, t}$ denotes the conditional volatility on the CAC40 stock index obtained from a $\operatorname{GARCH}(1,1)$ model in day t. The coefficients and the associated p-values in parentheses are estimated using heteroskedasticity-robust standard errors. For cases where parameters are not estimated, the cells contain a dash (一). Period: January 1, 1995-December $31,2019 .{ }^{*} \mathrm{p}<.1,{ }^{* *} \mathrm{p}<.05$, and $* * * \mathrm{p}$ $<.01$. 


\section{Table 10}

Deseasonalized trading volumes on the SBF250 stock index on subsequent days when temperatures return to normal levels

\begin{tabular}{|c|c|c|c|c|}
\hline SBF250 stock index & Model 1 & Model 2 & Model 3 & Model 4 \\
\hline Constant & $\begin{array}{c}0.01 \\
(0.31)\end{array}$ & $\begin{array}{c}0.01 \\
(0.36)\end{array}$ & $\begin{array}{c}0.01 \\
(0.32)\end{array}$ & $\begin{array}{c}0.01 \\
(0.42)\end{array}$ \\
\hline$D A Y S>30^{\circ} C_{t+1}$ & $\begin{array}{l}-0.01 \\
(0.81)\end{array}$ & - & - & - \\
\hline$D A Y S>30^{\circ} C_{t+2}$ & - & $\begin{array}{c}0.03 \\
(0.12)\end{array}$ & - & - \\
\hline$D A Y S>30^{\circ} C_{t+3}$ & - & - & $\begin{array}{c}0.00 \\
(0.99)\end{array}$ & - \\
\hline$D A Y S>30^{\circ} C_{t+4}$ & - & - & - & $\begin{array}{c}0.01 \\
(0.48)\end{array}$ \\
\hline $\operatorname{Ln}\left(V O L U M E_{S B F 250, t-1}\right)$ & $\begin{array}{c}0.42 * * * \\
(0.00)\end{array}$ & $\begin{array}{c}0.42 * * * \\
(0.00)\end{array}$ & $\begin{array}{c}0.42 * * * \\
(0.00)\end{array}$ & $\begin{array}{c}0.42 * * * \\
(0.00)\end{array}$ \\
\hline $\operatorname{Ln}\left(V O L U M E_{S B F 250, t-2}\right)$ & $\begin{array}{c}0.09 * * * \\
(0.00)\end{array}$ & $\begin{array}{c}0.09 * * * \\
(0.00)\end{array}$ & $\begin{array}{c}0.09 * * * \\
(0.00)\end{array}$ & $\begin{array}{c}0.09 * * * \\
(0.00)\end{array}$ \\
\hline $\operatorname{Ln}\left(V O L U M E_{M S C I U S A, t}\right)$ & $\begin{array}{c}0.44 * * * \\
(0.00)\end{array}$ & $\begin{array}{c}0.44 * * * \\
(0.00)\end{array}$ & $\begin{array}{c}0.44 * * * \\
(0.00)\end{array}$ & $\begin{array}{c}0.44 * * * \\
(0.00)\end{array}$ \\
\hline VOLATILITY $Y_{S B F 250, t}$ & $\begin{array}{l}-0.73 \\
(0.14)\end{array}$ & $\begin{array}{l}-0.73 \\
(0.17)\end{array}$ & $\begin{array}{l}-0.73 \\
(0.17)\end{array}$ & $\begin{array}{l}-0.73 \\
(0.23)\end{array}$ \\
\hline $\mathrm{R}^{2}$ & 0.45 & 0.45 & 0.45 & 0.45 \\
\hline $\mathrm{N}$ & 6,501 & 6,501 & 6,501 & 6,501 \\
\hline
\end{tabular}

Note: This table presents the trading volume reaction following days when temperatures in Paris return to normal levels (below $30^{\circ} \mathrm{C}$ ). The independent variables of interest $D A Y S>30^{\circ} C_{t+1}, D A Y S>30^{\circ} C_{t+2}, D A Y S>30^{\circ} C_{t+3}$, and $D A Y S>30^{\circ} C_{t+4}$ are dummy variables respectively coded as one for the first, the second, the third, and the fourth day following the day with hot weather in Paris and zero otherwise. The dependent variable, namely the daily deseasonalized trading volumes on the SBF250 stock index $\left(\operatorname{Ln}\left(V O L U M E_{S B F 250, t}\right)\right)$, are expressed in logarithmic

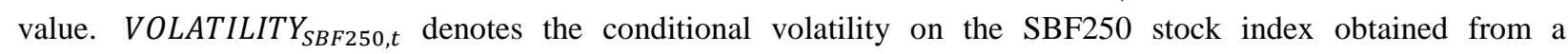
$\operatorname{GARCH}(1,1)$ model in day t. Least squares regressions are applied where the coefficients and the associated p-values in parentheses are estimated using heteroskedasticity-robust standard errors. For cases where parameters are not estimated, the cells contain a dash (一). Period: January 1, 1995-December 31, 2019. * $\mathrm{p}<.1, * * \mathrm{p}<.05$, and $* * * \mathrm{p}$ $<.01$ 